\title{
Effect of part-baking time, freezing rate and storage time on part-baked bread quality
}

\author{
Jesus Enrique GERARDO-RODRÍGUEZ1, Benjamín RAMÍREZ-WONG ${ }^{1}$ (D), Patricia Isabel TORRES-CHÁVEZ , \\ Ana Irene LEDESMA-OSUNA ${ }^{1}$, Elizabeth CARVAJAL-MILLÁN ${ }^{2}$, Jaime LÓPEZ-CERVANTES³ \\ María Irene SILVAS-GARCÍA ${ }^{1 *}$
}

\begin{abstract}
In the baking industry, different processes and methods of freezing have been used for breadmaking to preserve a quality comparable to that of fresh bread. In this study, the effect of part-baking time, freezing rate, and frozen storage time on part-baked French bread quality was determined. The bread was part-baked for 0,3 and $6 \mathrm{~min}$, frozen at slow $\left(0.15^{\circ} \mathrm{C} / \mathrm{min}\right)$ and fast $\left(1.75^{\circ} \mathrm{C} / \mathrm{min}\right)$ freezing rates, stored under freezing conditions for up to 56 days and thawed every 14 days. Part-baked bread was rebaked, and the SV and firmness at 2, 24 and $48 \mathrm{~h}$ were obtained. An experiment with a factorial design of $3 \times 2 \times 5$ ( 3 part-baking time, 2 freezing rates and 5 frozen storage times) with analysis of variance (ANOVA) at a confidence level of $95 \%$ was carried out. The highest SV was obtained at $6 \mathrm{~min}$ of part-baking at a slow freezing rate and decreased as the frozen storage time increased. In contrast, TPA showed that bread firmness increases when the specific volume decreases, and the highest firmness is at $0 \mathrm{~min}$ of part-baked time. Relatively long part-baking times allow for firm crumb formation with limited damage to the structure and therefore bread with optimal quality.
\end{abstract}

Keywords: gluten network; gelatinization; part-baked bread; retrogradation; starch.

Practical Application: The frozen dough industry will benefit from knowing the optimal processing conditions for the partially baked bread method, improving their product quality.

\section{Introduction}

Bread is consumed worldwide due to its versatility of preparation, energy contribution, and relatively low cost. Its elaboration consists of the fermentation of wheat dough and baking that allows for the development of the typical characteristics of bread of aroma, taste and texture (Pico et al., 2015). The main quality parameter is freshness, i.e., the most suitable and acceptable conditions of aroma, taste and texture for the consumer (Havet et al., 2000). However, bread is a short-shelf-life product, so its freshness is quickly reduced (Cauvain \& Young, 2008) due to physicochemical changes such as loss of moisture (staling and hardness) (Bárcenas et al., 2003) and volatile aroma compounds (Almeida et al., 2016; Pico et al., 2015) and microbiological changes (mold growth) (Axel et al., 2017). Reduced bread quality causes large quantities of bread products to be continuously discarded, resulting in significant economic losses for producers.

The artisan producers of loaves and bakery industries work to prolong the shelf life of bread. For this reason, studies have been carried out in which researchers have used different methods for production and preservation, such as intelligent packaging (controlled or modified atmospheres) (Khoshakhlagh et al., 2014) and additives (gums, emulsifiers, hydrocolloids, and others) (Halagarda, 2017), or variations in manufacturing, such as dough freezing or partial baking and freezing (Ribotta et al., 2004).
Partial baked and freezing processes are performed following the conventional procedure but include a short bake until the structure is fixed before freezing without developing a brown color and crisp crust (Almeida et al., 2016). Part-baked bread has the advantage of requiring less time in the final preparation, which has led to its relatively frequent implementation by industries and artisanal producers (Rosell \& Gómez, 2007). In contrast to frozen bread doughs, where the main problem is the loss of bread volume due to damage to yeast and the weakening of the gluten-starch structure, partially baked breads develop a sponge structure but are not baked fully, which allows for the remainder of the bake time to be completed after prolonged storage, conserving sensorial attributes of freshly baked bread and the volume of the bread. However, the partially baked bread could undergo physicochemical changes during freezing, frozen storage and thawing that are related to water crystals and redistribution in the complete system, affecting the final texture of the bread and accelerating aging. Another problem present in partially baked bread due to interrupted baking and freezing is the flaking of the crust and accelerated aging due to retrogradation in storage (Lucas et al., 2005).

Some authors, such as Almeida et al. (2016), Hejrani et al. (2017), Borczak et al. (2015), and Izadi Najafabadi et al. (2014), have studied bread quality to improve the volume, firmness, and loss of moisture due to retrogradation or aging. However, 
most of the studies were conducted to determine the optimum mixing and proofing time, so more studies are still necessary on the rate of freezing and baking conditions to obtain partially baked bread with improved quality. Therefore, it is necessary to study how the freezing rate and storage time can affect partially baked bread properties. The aim of this work was to determine the effect of partial baking time and freezing rate on bread quality. In this way, the best conditions of production were determined to obtain partially baked bread with the qualities of fresh bread.

\section{Materials and methods}

\subsection{Raw materials}

Flour was obtained from milling the Kronstad wheat variety cultivated from Yaqui Valley. Fresh yeast was obtained from Guadalajara, México (Azteca S.A. of C.V). Salt and commercial shortening were obtained from Hermosillo, México.

Flour characterization was conducted as follows (AACC, 1999): moisture content Method 44-01.01, protein content Method 46-12.01, and ash content Method 08-01.01, were determined by corresponding standard methods. Rheological characterization of the flour was conducted using a farinograph (Brabender Instruments, model 810143, South Hackensack, NJ, USA) Method 54-21.02 and an alveograph (Chopin Instruments, Villeneuve-La-Garenne, France Method 54-30.02.

\subsection{Dough preparation}

The wheat dough formula for French bread consisted of wheat flour (100\%), shortening (5\%), fresh yeast (Saccharomyces cerevisiae, $3 \%$ ), salt (1.5\%) and $62 \%$ water (determined by farinography). Ingredients are expressed on a flour weight basis. A mixer (National MFG brand, Lincoln NE, US) was used for $4 \mathrm{~min}$ for dough development. The dough was divided into $50 \mathrm{~g}$ portions and fermented in a chamber (National MFG brand, Lincoln, NE, US) at $30^{\circ} \mathrm{C}$ and a relative humidity (RH) of $85 \%$ for 60 min (Silvas-García et al., 2014).

\subsection{Part-baking and freezing of dough}

Dough was part-baked for 0,3 or 6 min at $250{ }^{\circ} \mathrm{C}$ using an oven (National MFG, Lincoln NE, US). Part-baking times were previously determined to obtain different degrees of crumb formation considering that 10 mins of baking resulted in fully baked bread. The part-baked bread was cooled for $2 \mathrm{~h}$ until reaching $25^{\circ} \mathrm{C}$ and placed into a hermetic bag. The frozen dough (0 min of part-baked) and part-baked bread were frozen until reaching $-20^{\circ} \mathrm{C}$ at the slow freezing rate $\left(0.15^{\circ} \mathrm{C} / \mathrm{min}\right)$ in a freezer (Frigidaire, model GLFC1526FW, Mississauga, Ont., Canada) or fast freezing rate $\left(1.75^{\circ} \mathrm{C} / \mathrm{min}\right)$ in an ultrafreezer (Thermo Fisher Scientific LCC, model UXF40086A62, Ashville, NC USA). The freezing rate was previously determined by measuring the time needed to reach $-20^{\circ} \mathrm{C}$ using a thermopar system.

\subsection{Frozen storage and rebaking the part-baked bread}

The frozen storage of part-baked bread was carried out in a freezer (Frigidaire, model GLFC1526FW, Mississauga, Ont., Canada) at $-20{ }^{\circ} \mathrm{C}$ for 56 days. During storage, samples were taken every 14 days for evaluation. The frozen storage time was determined according to previous studies (Gerardo-Rodriguez et al., 2016). Part-baked bread was thawed in a fridge for $2 \mathrm{~h}$ until reaching $4{ }^{\circ} \mathrm{C}$ and rebaked at $250{ }^{\circ} \mathrm{C}$ to complete 10 mins of baking time (10, 7 and 4 mins of rebaking time for the samples part-baked for 0, 3 and 6 mins of part-baked, respectively).

\subsection{Specific Volume (SV) of bread}

The SV of part-baked French bread was determined in full baked bread $2 \mathrm{~h}$ after baking by measuring the volume according to the rapeseed displacement method using a measurer (National MFG Co., PUP, Lincoln, NE, USA). Loaf weight was recorded (OHAUS 700/800 series, US), and the specific volume was calculated as the ratio of the bread volume and weight (AACC Method 10-05.01).

\subsection{Firmness of bread}

The texture of the bread was measured using texture profile analysis (TPA). For TPA, a texture analyzer (Stable Micro System Texture Analyzer model TA. TX Plus) was used according to a modification of AACC Method 10-09.01 (American Association of Cereal Chemists, 1999). Crumb cubes of $2 \mathrm{~cm}$ per side were prepared for evaluation, and the following conditions were used: double compression, bread deformation of $50 \%$, a pretest speed of $1 \mathrm{~mm} / \mathrm{s}$, a test speed of $3 \mathrm{~mm} / \mathrm{s}$, and a posttest speed of $10 \mathrm{~mm} / \mathrm{s}$. The primary parameters obtained for bread texture as firmness were hardness, resilience and springiness.

\subsection{Experimental design and statistical analysis}

A factorial design of $2 \times 3 \times 5$ was used. The factors and levels for part-baked bread were part-baking time $(0,3$, or $6 \mathrm{~min})$, storage time $\left(0,14,28,42\right.$, or 56 days), and freezing rate (slow: $0.15^{\circ} \mathrm{C} / \mathrm{min}$ and fast: $1.75^{\circ} \mathrm{C} / \mathrm{min}$ ). Statistical analysis was performed with analysis of variance (ANOVA) and 95\% significance. Tukey's test was used to find means that were significantly different from each other. In addition, the Pearson correlation coefficient was used to find linear correlation between variables. Statistical analysis was performed using SAS 9.4 statistical software.

\section{Results and discussion}

The results of flour characterization are shown in Table 1. The flour showed a high ash content, which, according to studies by Indrani et al. (2007), is negatively correlated with alveographic parameters. However, values such as work (W) were high (442), which could be due to a high protein content (12.5\%), indicating that the flour is resistant and appropriate for bread making. Alveograph $\mathrm{P} / \mathrm{L}$ represents the balance of elasticity and extensibility, which are parameters that influence the spread ratio of a dough and the size of the film formed during bread processing. The value obtained for $\mathrm{P} / \mathrm{L}$ was 1.38 , and according to Chen \& D'Appolonia (1985), an alveograph P/L value close to 1 is necessary to have a correct balance of elasticity and extensibility for breadmaking. Farinograph parameters were also determined, finding a stability of $17.62 \mathrm{~min}$ and development time of $1.5 \mathrm{~min}$, which is typical for a high-gluten-content flour (Mohammed et al., 2014). For the present study, a strong flour 
Table 1. Physicochemical and rheological properties of flour obtained from the Kronstad wheat variety.

\begin{tabular}{cc}
\hline Determination & Mean \\
\hline Moisture content $(\%)$ & $14.15 \pm 0.08^{\mathrm{a}}$ \\
Ash content $(\%)^{\mathrm{b}}$ & $0.96 \pm 0.02$ \\
Protein content $(\%)^{\mathrm{b}}$ & $12.50 \pm 0.14$ \\
Farinograph & $17.62 \pm 0.53^{\mathrm{a}}$ \\
Dough stability (min) & $11.5 \pm 0.7$ \\
Development time (min) & 60 \\
Water absorption (\%) & $129 \pm 3^{\mathrm{a}}$ \\
Alveograph & $93.33 \pm 5.86$ \\
Tenacity (P) $(\mathrm{mm})$ & $442 \pm 27$ \\
Extensibility (L) $(\mathrm{mm})$ & $1.38 \pm 0.08$ \\
Work $(\mathrm{W})\left(10^{-4} \mathrm{~J}\right)$ & \\
Tenacity/elasticity relation $(\mathrm{P} / \mathrm{L})$ &
\end{tabular}

${ }^{\mathrm{a}}$ Standard deviation; ${ }^{\mathrm{b}}$ Dry basis.
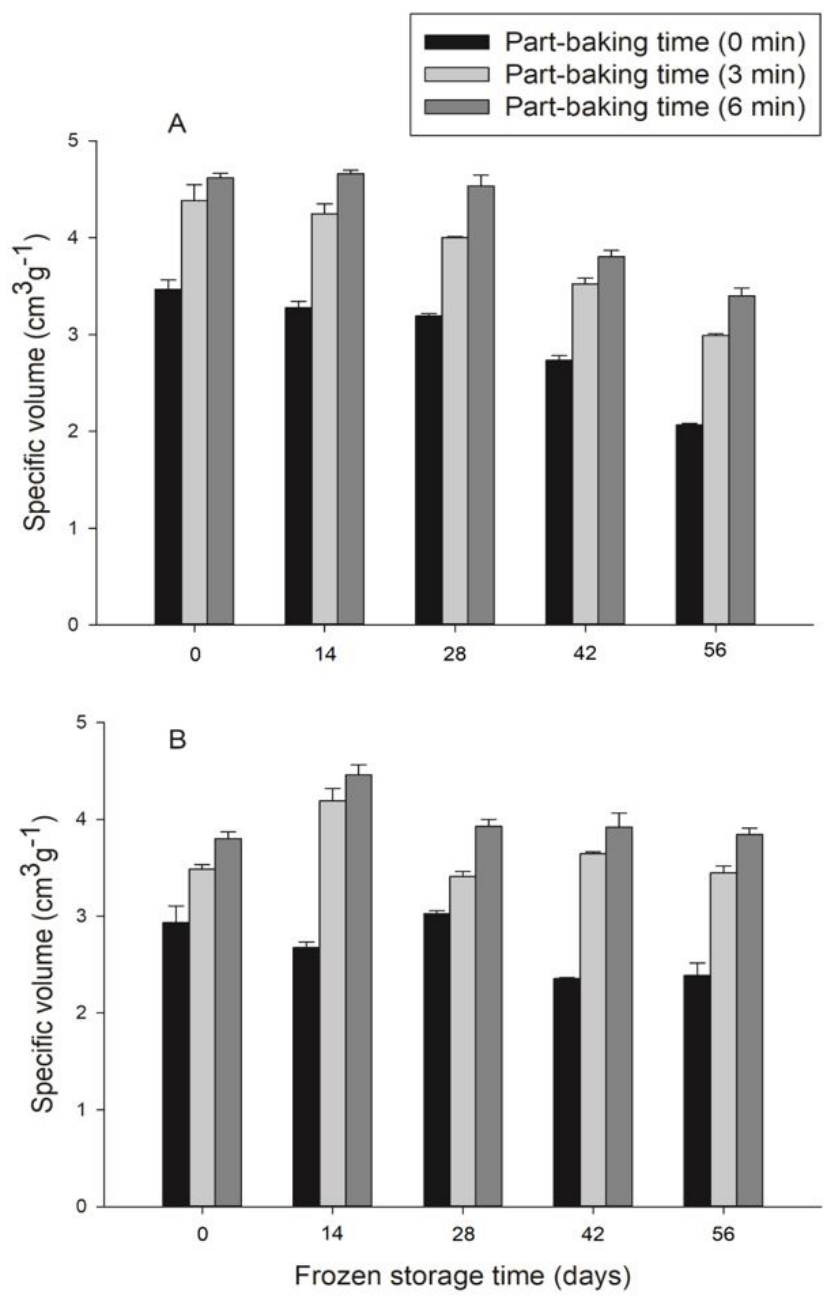

Figure 1. Effect of part-baking time and frozen storage time on the specific volume of part-baked bread frozen at a (A) slow freezing rate and (B) fast freezing rate.

is necessary due to the effects of freezing on the nonpartially baked samples; however, samples part-baked for 3 and $6 \mathrm{~min}$ could not necessarily require a strong flour, as too high a volume may cause the bread to collapse after part-baking.

\subsection{Specific volume of French bread}

According to the analysis of variance (ANOVA), all treatments and interactions of part-baking time, freezing rate, and storage time resulted in significant differences $(\mathrm{P}<0.01)$ for the SV of French bread. Figure 1A shows the interaction effect of part-baking time and storage time on the SV of part-baked bread frozen at a slow freezing rate. With 6 min of part-baking, the specific volume values are higher than those of the sample part-baked for 3 and $0 \mathrm{~min}$ for all frozen storage times. Differences in the volume could be because the frozen dough subjected to $0 \mathrm{~min}$ of part-baking was fully fermented and contained gas bubbles that could collapse, resulting in a less stable structure than the sponge formed during 3 and 6 min of part-baking. On the other hand, when dough with 0 min of baking is frozen, the formation of ice crystals within the dough causes structural damage and yeast lysis (Phimolsiripol et al., 2008) due to water redistribution, and the release of glutathione due to yeast lysis damages the disulfide bonds in sulfhydryl groups by reducing SS to SH- (Casey \& Foy, 1995). This causes weakening in the gluten network, which is unable to retain $\mathrm{CO}_{2}$ (Yi \& Kerr, 2009). With 3 and 6 min of baking, the rigid structure formed by protein denaturing and starch gelatinization reactions prevents the decrease in bread volume; however, for 3 min of part-baking, free water could remain available for freezing and could still be redistributed and form large ice crystals. With the increase in frozen storage time, the specific volume decreases in relation to the development of large crystals during recrystallization and water redistribution that do not return to their original sites, and this water is lost during thawing. This loss of water is reflected as a relatively dense crumb and rapid retrogradation of starch by loss of water. Additionally, due to crumb moisture migration during storage and thawing, more pronounced evaporation during the rebaking phase occurred in the bread, resulting in the lowest bread mass and crumb, which also affected the SV. Bosmans et al. (2014) found that bread with an intermediate frozen storage period reduced the specific volume of fully baked bread due to limited crust formation during the first baking step and the resultant high crust.

Figure $1 \mathrm{~B}$ shows the interaction effect of part-baking time and storage time on the specific volume of part-baked bread frozen at the fast freezing rate, in which a similar behavior of increase in specific volume with increasing part-baking time is observed; however, the effect of frozen storage time is not clear in bread frozen at the fast freezing rate. It is possible that the fast freezing rate allows for the formation of short crystals (nucleation stage), which decreases the effects of temperature fluctuations during frozen storage; however, more studies about fast freezing and frozen storage in part-baked bread are needed to confirm this result.

\subsection{Firmness of bread}

A texture profile analysis of bread was carried out to determine the main parameters of bread quality, hardness, resilience and springiness; however, the most significantly impact parameter was hardness, reported as firmness, which will be described below. According to the analysis of variance (ANOVA), there was a significant difference $(\mathrm{P}<0.01)$ in 
the firmness of part-baked bread compared to that of fully baked bread. Baking is responsible for several changes in the molecular structure of dough due to protein denaturation and the evaporation of water leading to the gelatinization of starch forming a semisolid material with viscoelastic behavior in a rigid crumb capable of supporting the structure formed during fermentation. Figure $2 \mathrm{~A}, \mathrm{~B}$ and $\mathrm{C}$ shows the effect of part-baking time and frozen storage time on the firmness of part-baked bread frozen at the slow freezing rate 2,24, and $48 \mathrm{~h}$ after baking. With 6 min of part-baking, the bread had lower firmness values than those of the dough that was not subjected to part-baking prior to freezing. On the other hand, with $0 \mathrm{~min}$ of part-baking (frozen dough), the sample still exhibited dough behavior and not the sponge behavior exhibited by the other prebaked samples. In this case, the firmness of the crumb was higher because the dough was frozen without previous partial

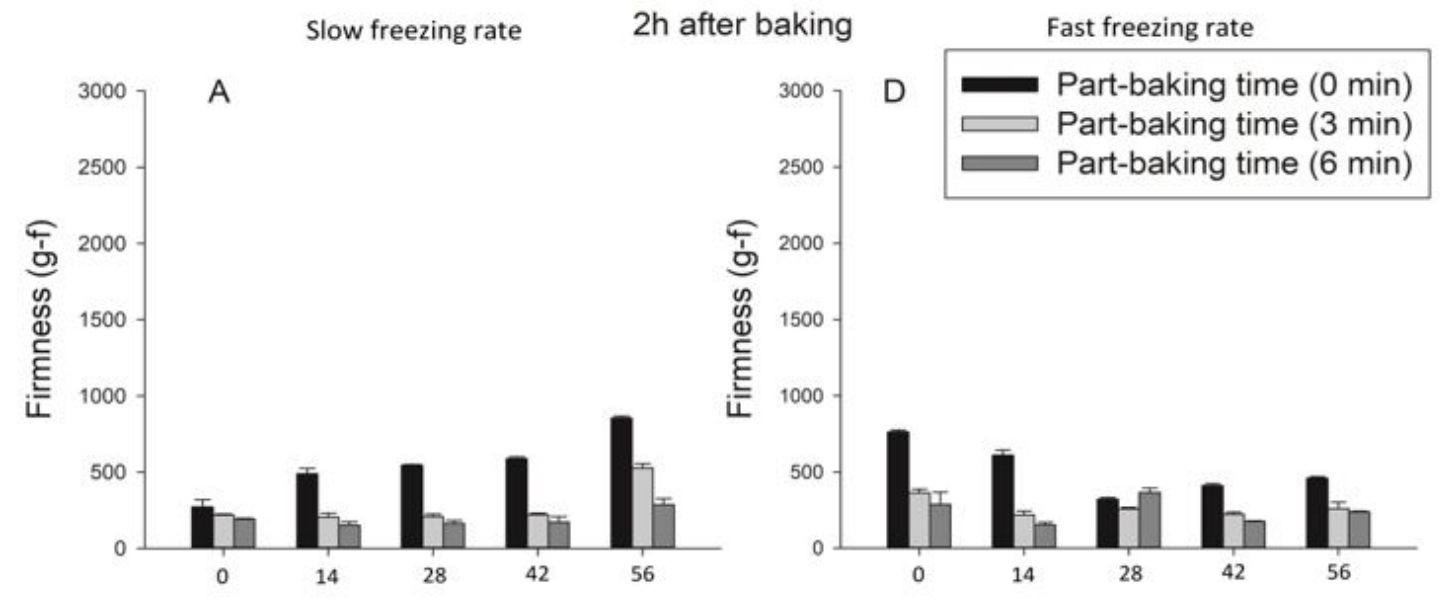

$24 \mathrm{~h}$ after baking
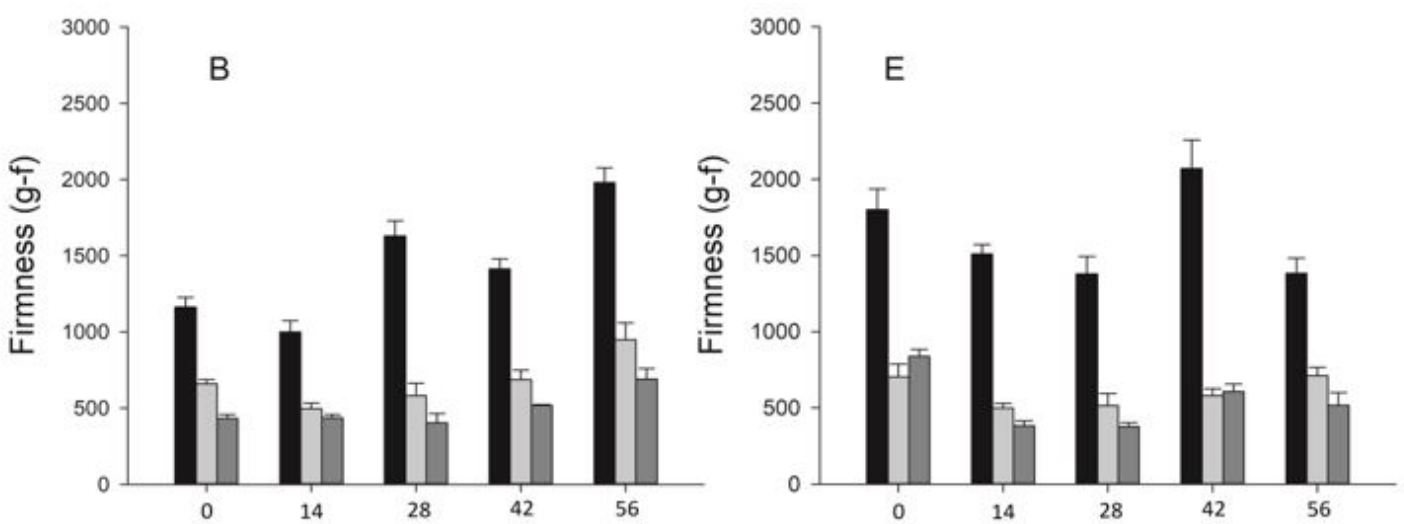

$48 \mathrm{~h}$ after baking
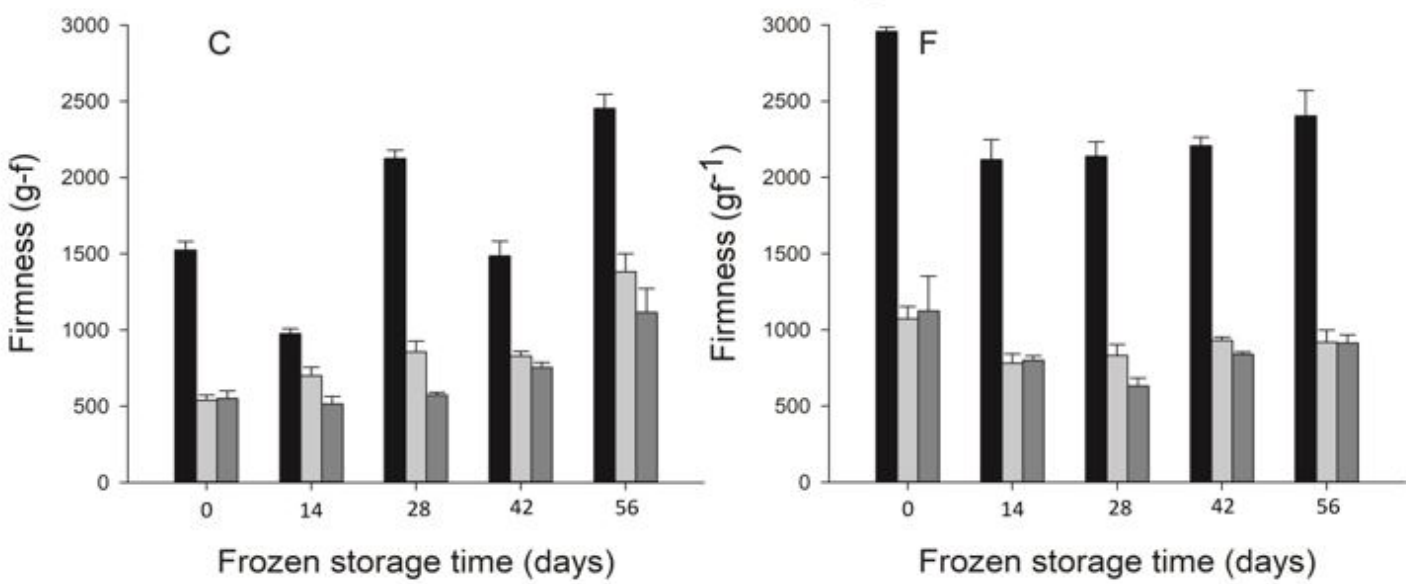

Figure 2. Effect of part-baking time and frozen storage time on the firmness of part-baked bread A, B and C frozen at slow and fast freezing rates and storage bread at 2, 24 and $48 \mathrm{~h} . \mathrm{D}, \mathrm{E}$ and F, frozen at fast freezing rate and storage bread at 2, 24 and $48 \mathrm{~h}$. 
baking, causing greater damage to the gluten due to greater amounts of free water in the dough and the breaking of the continuity of the gluten network and water redistribution. In addition, the yeast suffered damage either by increasing osmotic pressure or by breaking the cell membrane. Defrosting and baking, it gives rise to bread without $\mathrm{CO}_{2}$ retention capacity, which creates bread with a low volume and high firmness. On the other hand, with 3 and 6 min of part-baking time, the formation of a relatively firm crumb is achieved due to protein denaturation and starch gelatinization (sponge), which makes it possible to retain its original volume before freezing and retains more water than the unbaked sample.

With increasing freezing storage time, an increase in firmness is observed for all the treatments. At 0 days of frozen storage, the firmness values are lower than those at the other storage times. Every 14 days, the firmness of the crumb generally increased (with exceptions). From day 0 to day 56, there is a notable increase in firmness, which could be minimized by freezing bread with a fast freezing rate (Giannou \& Tzia, 2008). At long frozen storage durations, frozen water is more susceptible to melting due to temperature fluctuations than at short freezing storage durations, causing water redistribution and the formation of large ice crystals. Bárcenas et al. (2003) found that freezing-thaw cycles and frozen storage time in part-baked bread produces a progressive increase in the retrogradation temperature range, indicating that structural changes in amylopectin occurred.

When comparing Figures $2 \mathrm{~A}, \mathrm{~B}$ and $\mathrm{C}$, the effect of time after rebaking, i.e., 2, 24, and $48 \mathrm{~h}$ after baking, was observed. The result shows that the fresh bread $(2 \mathrm{~h})$ has less firmness than those samples at 24 and $48 \mathrm{~h}$ after rebaking. Some researchers, such as Anon et al. (2004), have studied the firmness of stale bread and confirmed that starch retrogradation is responsible for the increasing firmness of aging bread. Bread sampled $24 \mathrm{~h}$ after rebaking show the effects of starch retrogradation and syneresis, which gave rise to bread aging (Morgan et al., 1997). The above is probably caused by moisture loss resulting from the syneresis to which amylose is exposed. Retrogradation is a result of the expulsion of moisture due to a rearrangement of the starch ramifications, resulting in a firm crumb.

Figure 2D, E and $\mathrm{F}$ shows the effect of part-baking time and frozen storage time on the firmness of part-baked bread frozen at a fast freezing rate at 2,24, and $48 \mathrm{~h}$ after baking. Although there are exceptions in samples stored for prolonged frozen storage times, higher firmness values are observed with the fast freezing rate than with the slow freezing rates. However, as
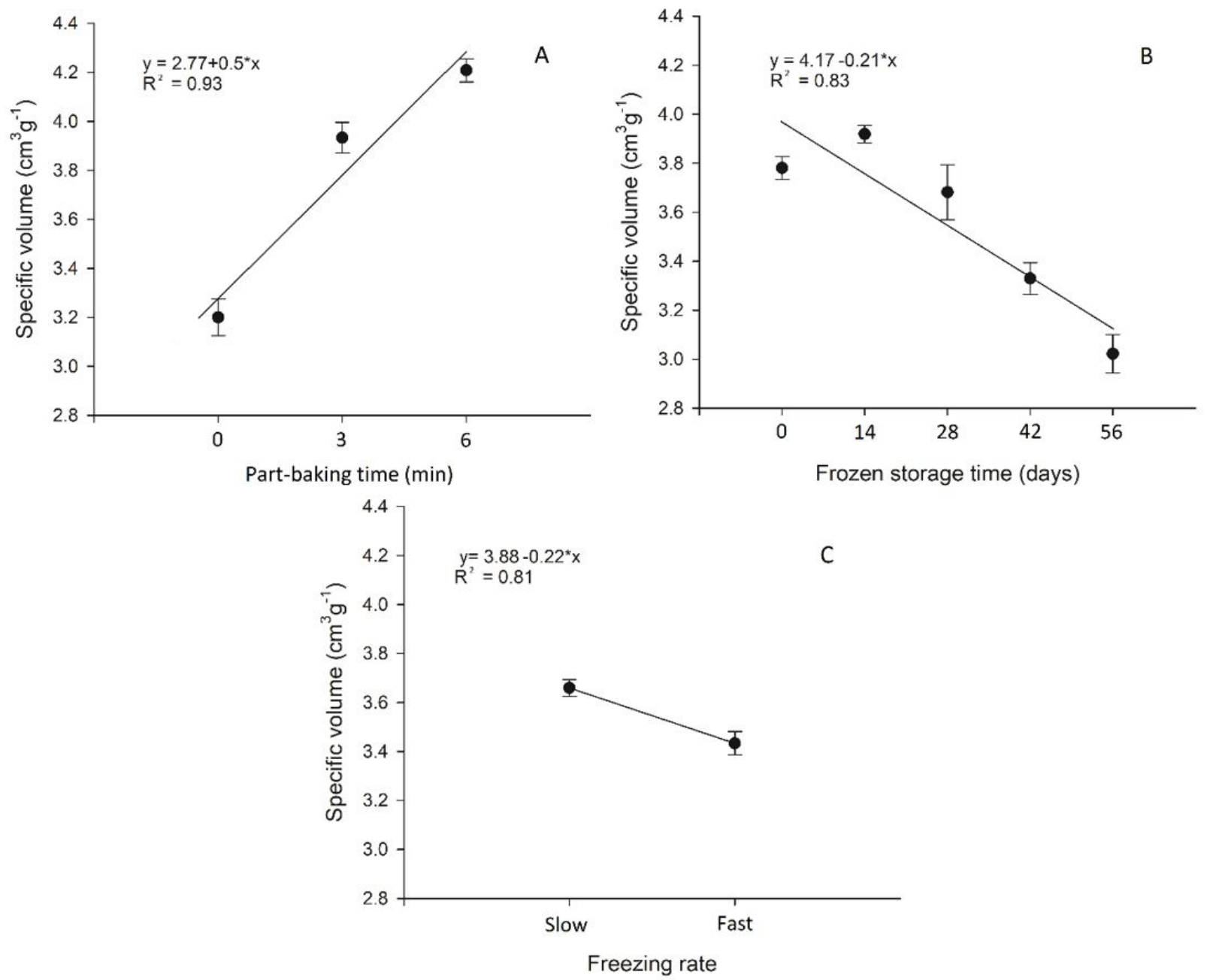

Figure 3. Linear regressions between specific volume of breadspecific and part-baking time (A), frozen storage time (B) and freezing rate (C). 


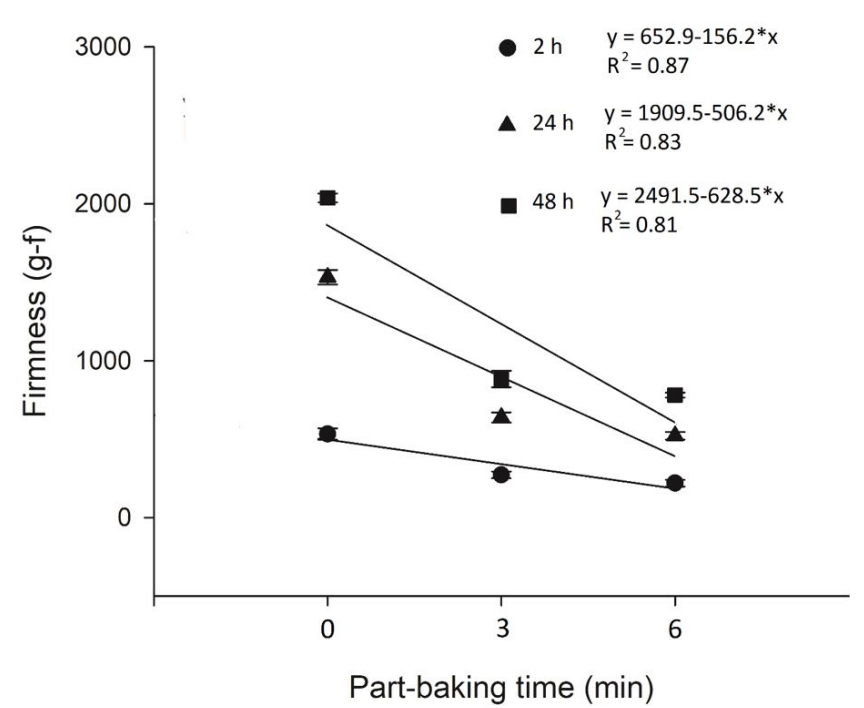

Figure 4. Linear regressions between specific firmness of bread stored at 2,24 and $48 \mathrm{~h}$.

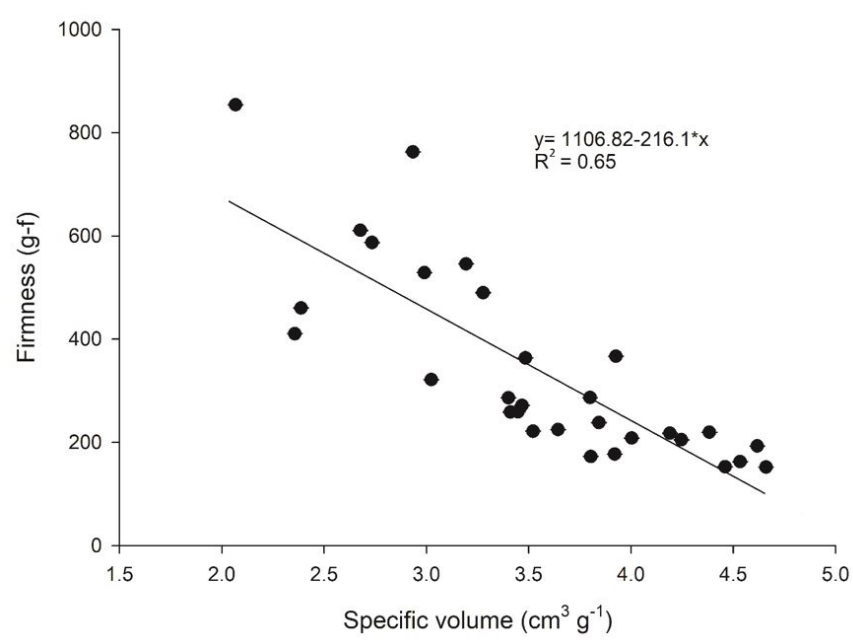

Figure 5. Linear regressions between specific volume of bread and firmness of bread at $2 \mathrm{~h}$ of storage.

the frozen storage time increases, part-baked bread frozen at the fast freezing rate is more stable and increases after 28 days. This can be explained by the low water redistribution that remains in bread during frozen storage, which usually occurs when moisture nuclei are formed by using a fast freezing rate (Le Bail et al., 1998). In unbaked samples (frozen dough), this moisture in the nucleation stage conglomerates in the cytoplasm of the yeast, breaking the membrane and releasing glutathione, a substance that reduces the disulfide bonds that link subunits of glutenins, which increases its molecular weight to form an elastic gluten network (Meziani et al., 2011). In a study by Tao et al. (2016) with frozen sweet dough, rapid retrogradation was observed, and the relative crystallinity increased at different freezing rates; however, this phenomenon is not clear for part-baked bread.

At $2 \mathrm{~h}$ after rebaking, it is possible to observe lower firmness than that of older bread. At 24 and $48 \mathrm{~h}$, there is a greater degree of retrogradation than at $2 \mathrm{~h}$ after rebaking; therefore, the hardness of the crumb is greater in these older samples. The behavior of increasing firmness in bread with freezing rate and storage time is the same 2, 24 and $48 \mathrm{~h}$ after rebaking, which changes only the firmness values.

\subsection{Correlation among experimental variables and bread quality}

Bread quality parameters were analized in order to demostrate the effect of part-baking time, freezing rate and frozen storage time. The most of the bread quality parameters evaluated as specific volume and firmness had significant linear correlation with the experimental variables. Specific volume had significant correlation with part-baking time, frozen storage time and freezing rate. Bread firmness had a significant correlation with part-baking time and bread storage time.

Figure $3 \mathrm{~A}$ presents a significant linear relatinoship between specific volume of bread and part-baking time $\left(R^{2}=0.93\right)$ and a positive slope. Figure 3B presents a significant linear relationship between specific volume and frozen storage time $(\mathrm{R} 2=0.83)$ with a negative slope. Figure 3C presents a significant linear relationship between specific volume and freezing rate $\left(R^{2}=0.81\right)$ with a negative slope. These regressions support that using longer part-baking time the bread keep its quality, while t frozen storage time damages the strcuture due to water recrystalization, however, lower specific volume for fast freezing rate was observed, which is not complety understood. Figure 4 presents significant linear relationships among firmness of bread at 2, 24 and $48 \mathrm{~h}$ of bread storage and part-baking time $\left(\mathrm{R}^{2}=0.87,2 \mathrm{~h} ; \mathrm{R}^{2}=0.83,24 \mathrm{~h}\right.$; $\mathrm{R}^{2}=0.81,48 \mathrm{~h}$ ) with negative slopes. Autors such as Zhang et al. (2018) have reported the effect of starch retrogradation, which causes the increase of firmness on bread due to storage. On the other hand, Figure 5 shows the linear regression of specific volume and firmness of bread at $2 \mathrm{~h}$ which had significant correlation $\left(R^{2}=0.65\right)$ with negative slope indicating that with higher specific volume the firmness decrease. This result has been widely reported previously (Mudgil et al., 2016; Jekle et al., 2018; Masure et al., 2019).

\section{Conclusions}

The part-baked time and the freezing rate significantly affect the quality, specific volume and firmness parameters of pre-baked bread during the entire frozen storage time. Prebaking and subsequent freezing allows for extension of the shelf life of bread. The volume of bread is preserved after the entire freezing, thawing and baking process when partially baked before storage in contrast to the volume of bread produced with frozen dough, which loses its total capacity to retain $\mathrm{CO}_{2}$, producing bread with low volume and high density and firmness. At prolonged storage times, the bread volume also decreases and the firmness increases because they are inversely proportional. Therefore, considering the advantages of part-baked bread over frozen dough, the former is more convenient than the latter due to greater retention of quality and timesavings, and the optimal process is a relatively long prebake time, a fast freezing rate, and short freezing storage time. 


\section{References}

American Association of Cereal Chemists - AACC. (1999). Approved Methods of the AACC. St. Paul, MN. EUA: American Association of Cereal Chemists.

Almeida, E. L., Steel, C. J., \& Chang, Y. K. (2016). Par-baked bread technology: formulation and process studies to improve quality. Critical Reviews in Food Science and Nutrition, 56(1), 70-81. http:// dx.doi.org/10.1080/10408398.2012.715603. PMid:25000472.

Anon, M., Bail, A. 1., Leon, A., Hui, Y., Cornillon, P., Legaretta, I., Lim, M., Murrell, K., \& Nip, W. K. (2004). Effect of freezing on dough ingredients. In Y. H. Hui, P. Cornillon, I. G. Legaretta, M. H. Lim, K. D. Murrell \& W-K. Nip (Eds.), Handbook of frozen foods (pp. 571-580). New York: Marcel Dekker.

Axel, C., Zannini, E., \& Arendt, E. (2017). Mold spoilage of bread and its biopreservation: a review of current strategies for bread shelf life extension. Critical Reviews in Food Science and Nutrition, 57(16), 3528-3542. http://dx.doi.org/10.1080/10408398.2016.1147 417. PMid:26980564.

Bárcenas, M. E., Haros, M., Benedito, C., \& Rosell, C. M. (2003). Effect of freezing and frozen storage on the staling of part-baked bread. Food Research International, 36(8), 863-869. http://dx.doi.org/10.1016/ S0963-9969(03)00093-0.

Borczak, B., Sikora, E., Sikora, M., Kapusta-Duch, J., \& Rosell, C. M. (2015). Starch digestibility index and antioxidative properties of partially baked wheat-flour bakery with an addition of dietary fibre. Stärke, 67(11-12), 913-919. http://dx.doi.org/10.1002/star.201500029.

Bosmans, G. M., Lagrain, B., Ooms, N., Fierens, E., \& Delcour, J. A. (2014). Storage of parbaked bread affects shelf life of fully baked end product: a1H NMR study. Food Chemistry, 165, 149-156. http:// dx.doi.org/10.1016/j.foodchem.2014.05.056. PMid:25038661.

Casey, G. P., \& Foy, J. J. (1995). Yeast performance in frozen doughs and strategies for improvement. In K. Lorenz \& J. Brummer (Eds.), Frozen and refrigerated doughs and batters. Minnesota: American Association of Cereal Chemists.

Cauvain, S., \& Young, L. (2008). Bakery food manufacture and quality: water control and effects (2nd ed.). Ames: John Wiley \& Sons. . http:// dx.doi.org/10.1002/9781444301083.

Chen, J., \& D’Appolonia, B. L. (1985). Alveograph studies on hard redspring wheat flour. Cereal Foods World, 30, 862-870.

Gerardo-Rodriguez, J. E., Ramirez-Wong, B., Ledesma-Osuna, A. I., Medina-Rodriguez, C. L., Ortega-Ramirez, R., \& Silvas-Garcia, M. I. (2016). Management of freezing rate and trehalose concentration to improve frozen dough properties and bread quality. Food Science and Technology (Campinas), 37(1), 59-64. http://dx.doi. org/10.1590/1678-457x.00482.

Giannou, V., \& Tzia, C. (2008). Crioprotective rol of exogenous trehalose in frozen dough products. Food and Bioprocess Technology, 1(3), 276-284. http://dx.doi.org/10.1007/s11947-007-0008-z.

Halagarda, M. (2017). Effects of trehalose and dough additives incorporating enzymes on physical characteristics and sensory properties of frozen savory Danish dough. LWT, 86, 603-610. http:// dx.doi.org/10.1016/j.lwt.2017.08.048.

Havet, M., Mankai, M., \& Le Bail, A. (2000). Influence of the freezing condition on the baking performances of French frozen dough. Journal of Food Engineering, 45(3), 139-145. http://dx.doi.org/10.1016/ S0260-8774(00)00050-9.

Hejrani, T., Sheikholeslami, Z., Mortazavi, A., \& Davoodi, M. G. (2017). The properties of part baked frozen bread with guar and xanthan gums. Food Hydrocolloids, 71, 252-257. http://dx.doi.org/10.1016/j. foodhyd.2016.04.012.
Indrani, D., Manohar, R. S., Rajiv, J., \& Rao, G. V. (2007). Alveograph as a tool to assess the quality characteristics of wheat flour for parotta making. Journal of Food Engineering, 78(4), 1202-1206. http://dx.doi. org/10.1016/j.jfoodeng.2005.12.032.

Izadi Najafabadi, L., Le-Bail, A., Hamdami, N., Monteau, J.-Y., \& Keramat, J. (2014). Impact of baking conditions and storage temperature on staling of fully and part-baked Sangak bread. Journal of Cereal Science, 60(1), 151-156. http://dx.doi.org/10.1016/j.jcs.2014.02.004.

Jekle, M., Fuchs, A., \& Becker, T. (2018). A normalized texture profile analysis approach to evaluate firming kinetics of bread crumbs independent from its initial texture. Journal of Cereal Science, 81, 147-152. http://dx.doi.org/10.1016/j.jcs.2018.04.007.

Khoshakhlagh, K., Hamdami, N., Shahedi, M., \& Le-Bail, A. (2014). Quality and microbial characteristics of part-baked Sangak bread packaged in modified atmosphere during storage. Journal of Cereal Science, 60(1), 42-47. http://dx.doi.org/10.1016/j.jcs.2014.01.014.

Le Bail, A., Havet, M., \& Pasco, M. (1998). Influence of the freezing rate and of storage duration on the gassing power of frozen bread dough. In Proceedings of the Symposium of the International Institute of Refrigeration. Paris: Institut International du Froid.

Lucas, T., Quellec, S., Le Bail, A., \& Davenel, A. (2005). Chilling and freezing of part-baked breads. II. Experimental assessment of water phase changes and of structure collapse. Journal of Food Engineering, 70(2), 151-164. http://dx.doi.org/10.1016/j.jfoodeng.2004.09.021.

Masure, H. G., Wouters, A. G. B., Fierens, E., \& Delcour, J. A. (2019). Impact of egg white and soy proteins on structure formation and crumb firming in gluten-free breads. Food Hydrocolloids, 95, 406417. http://dx.doi.org/10.1016/j.foodhyd.2019.04.062.

Meziani, S., Jasniewski, J., Gaiani, C., Ioannou, I., Muller, J. M., Ghoul, M., \& Desobry, S. (2011). Effects of freezing treatments on viscoelastic and structural behavior of frozen sweet dough. Journal of Food Engineering, 107(3-4), 358-365. http://dx.doi.org/10.1016/j. jfoodeng.2011.07.003.

Mohammed, I., Ahmed, A. R., \& Senge, B. (2014). Effects of chickpea flour on wheat pasting properties and bread making quality. Journal of Food Science and Technology, 51(9), 1902-1910. http://dx.doi. org/10.1007/s13197-012-0733-9. PMid:25190845.

Morgan, K. R., Hutt, L., Gerrard, J., Every, D., Ross, M., \& Gilpin, M. (1997). Staling in starch breads. The effect of anti-staling a-amylase. Stärke, 49(2), 54-59. http://dx.doi.org/10.1002/star.19970490204.

Mudgil, D., Barak, S., \& Khatkar, B. S. (2016). Optimization of bread firmness, specific loaf volume and sensory acceptability of bread with soluble fiber and different water levels. Journal of Cereal Science, 70, 186-191. http://dx.doi.org/10.1016/j.jcs.2016.06.009.

Phimolsiripol, Y., Siripatrawan, U., Tulyathan, V., \& Cleland, D. (2008). Effects of freezing and temperature fluctuations during frozen storage on frozen dough and bread quality. Journal of Food Engineering, 84(1), 48-56. http://dx.doi.org/10.1016/j.jfoodeng.2007.04.016.

Pico, J., Bernal, J., \& Gómez, M. (2015). Wheat bread aroma compounds in crumb and crust: A review. Food Research International, 75, 200215. http://dx.doi.org/10.1016/j.foodres.2015.05.051. PMid:28454949.

Ribotta, P. D., Perez, G. T., Leon, A. E., \& Anon, M. C. (2004). Effect of emulsifier and guar gum on micro structural, rheological and baking performance of frozen bread dough. Food Hydrocolloids, 18(2), 305-313. http://dx.doi.org/10.1016/S0268-005X(03)00086-9.

Rosell, C. M., \& Gómez, M. (2007). Frozen dough and partially baked bread: an update. Food Reviews International, 23(3), 303-319. http:// dx.doi.org/10.1080/87559120701418368.

Silvas-García, M. I., Ramírez-Wong, B., Torres-Chavez, P. I., CarvajalMillan, E., Barrón-Hoyos, J. M., Bello-Pérez, L. A., \& Quintero-Ramos, 
A. (2014). Effect of freezing rate and storage time on gluten protein solubility, and dough and bread properties. Journal of Food Process Engineering, 37(3), 237-247. http://dx.doi.org/10.1111/jfpe.12079.

Tao, H., Wang, P., Wu, F., Jin, Z., \& Xu, X. (2016). Particle size distribution of wheat starch granules in relation to baking properties of frozen dough. Carbohydrate Polymers, 137, 147-153. http://dx.doi. org/10.1016/j.carbpol.2015.10.063. PMid:26686115.
Yi, J., \& Kerr, W. L. (2009). Combined effects of freezing rate, storage temperature and time on bread dough and baking properties. Food Science and Technology, 42, 1474-1483.

Zhang, Y., Li, D., Yang, N., Jin, Z., \& Xu, X. (2018). Comparison of dextran molecular weight on wheat bread quality and their performance in dough rheology and starch retrogradation. Lebensmittel-Wissenschaft + Technologie, 98, 39-45. http://dx.doi.org/10.1016/j.lwt.2018.08.021. 